\title{
Dolomite and dolomitization model - a short review
}

\begin{abstract}
Worldwide carbonate rocks are occurring abundantly. These carbonate rocks are a major class of sedimentary rocks group. Carbonate are sedimentary rocks formed at (or near) the Earth surface by precipitation from solution at surface temperatures. The two broad categories are limestone, which is composed of calcite or aragonite (different crystal forms of $\mathrm{CaCO} 3$ ) and dolostone, which is composed of the mineral dolomite (Ca Mg (CO3)2). Dolomite is not a simple mineral; it can have a variety of origin, can form as a primary precipitate, a diagenetic replacement, or as a hydrothermal/metamorphic phase, all that it requires is permeability, a mechanism that facilitates fluid flow, and a sufficient supply of magnesium. Dolomite can also form in lakes, on or beneath the shallow seafloor, in zones of brine reflux, and in early to late burial settings. It may form from seawater, from continental waters, from the mixing of basinal brines, the mixing of hypersaline brine with seawater, or the mixing of seawater with meteoric water, or via the cooling of basinal brines. Potential fluid sources are seawater and subsurface fluid of marine and/or meteoric origin: and addition $\mathrm{Mg}$ could be released from high-Mg calcite and smectite clays. The only abundant source of $\mathrm{Mg} 2+$ ions for early diagenetic surface and near-surface dolomitization is seawater. Dolomitization also creates new crystals, with new rhomb growth following the dissolution of less stable precursors. Dolomitization model and formation depend on the source dolomitization site and lastly, there must exist a favorable condition for a chemical reaction. One particular type of dolomite which may be a cement or a replacement is baroque dolomite, also called 'saddle' or 'white sparry' dolomite and known to mineral collectors as pearl spar. It is characterized by a warped crystal lattice.
\end{abstract}

Keywords: carbonates, dolomite, calcite, fluid source, dolomitization
Volume 2 Issue 5 - 2018

\author{
Mubashir Mehmood,' Muhammad Yaseen,2 \\ Emad Ullah Khan,' Muhammad Jehangir \\ $\mathrm{Khan}^{2}$ \\ 'Institute of Geology, University of the Punjab Lahore, Pakistan \\ ${ }^{2}$ Department of Geology, Abdul Wali Khan University, Mardan \\ Khyber Pakhtunkhwa Pakistan
}

Correspondence: Mubashir Mehmood, Institute of Geology, University of the Punjab Lahore, Pakistan, Email mubashirmehmood94@gmail.com

Received: July 13, 2018 | Published: September 18, 2018

\section{Introduction}

Carbonate rocks are a class of sedimentary rocks composed primarily of carbonate minerals. Carbonate are sedimentary rocks formed at (or near) the Earth surface by precipitation from solution at surface temperatures. The two major types are limestone, which is composed of calcite or aragonite (different crystal forms of $\mathrm{CaCO}_{3}$ ) and dolostone, which is composed of the mineral dolomite $\left(\mathrm{CaMg}\left(\mathrm{CO}_{3}\right)_{2}\right)$. Carbonate rocks are depositionally most simple but diagenetically most complex rocks of the world. There are a number of carbonate minerals which are formed by combining of one or more ion with the $\mathrm{CO}_{3} 2$ - ion. Dolomite is an anhydrous carbonate mineral composed of calcium magnesium carbonate, ideally $\mathrm{CaMg}\left(\mathrm{CO}_{3}\right)_{2}$. The term is also used for a sedimentary carbonate rock composed mostly of the mineral dolomite. An alternative name sometimes used for the dolomitic rock type is dolostone. Dolomite is an unusual carbonate mineral. It is common in ancient platform carbonates, yet it is rare in Holocene sediments Table $1 .{ }^{1}$

Table I Some important minerals

\begin{tabular}{ll}
\hline Mineral name & Chemical formula \\
\hline Calcite & $\mathrm{CaCO}_{3}$ \\
Aragonite & $\mathrm{CaCO}_{3}$ \\
Dolomite & $\mathrm{CaMg}\left(\mathrm{CO}_{3}\right)_{2}$ \\
Ankerite & $\mathrm{CaFe}\left(\mathrm{CO}_{3}\right)_{2}$ \\
Magnesite & $\mathrm{MgcO}_{3}$ \\
Siderite & $\mathrm{FecO}_{3}$ \\
\hline
\end{tabular}

\section{Dolomite types}

On the basis of the mode of formation, dolomites can broadly be divided into two groups: primary dolomite and secondary dolomite. ${ }^{2}$ Primary dolomite precipitate directly from aqueous solution, mostly at or near room temperature $\left(20-35^{\circ} \mathrm{C}\right)$, with no $\mathrm{CaCO}_{3}$ dissolution involved. ${ }^{3}$ However, dolomite can also form as a secondary phase replacing the precursor mineral calcite (dolomitization process). The widely accepted hypothesis of dolomitization is that limestone is transformed into dolomite by the dissolution of calcite followed by dolomite precipitation. ${ }^{4}$ That dolomite grows at the expense of calcite was demonstrated by the formation of dolomite on the edges and corners of calcite during dolomitization. ${ }^{5}$ During dolomitization dissolution of precursor mineral calcite will supply the much-needed $\mathrm{Ca}^{+2}$ wherein $\mathrm{Mg}^{+2}$ (and $\mathrm{CO}_{3}^{-2}$ ) is supplied by the dolomitizing fluid. ${ }^{6}$

\section{Formation of dolomite}

Dolomite is formed by the replacement of the calcite ions by the magnesium ions. Depending upon the ratio of the $\mathrm{Mg}$ ions in the crystal lattice they have different names (Figure 1). Modern dolomite formation has been found to occur under anaerobic conditions in supersaturated saline lagoons in Brazil. In the high-Mg calcite, there is a $0-32 \mathrm{~mol} \%$ of $\mathrm{Mg}$ substitution for $\mathrm{Ca}$. In the protodolomite there is roughly $55-60 \mathrm{Mol} \%$ Cain the lattice with incomplete segregation of $\mathrm{Ca}$ and $\mathrm{Mg}$ into separate layers In the stoichiometric dolomite has a 50:50 of $\mathrm{Ca}$ to $\mathrm{Mg}$ Ratio with the near perfect ordering of the $\mathrm{Mg}$ and $\mathrm{Ca}$ in alternate cation layers (Figure 2). Primary dolomite is indeed infrequent and often forms in lakes and lagoons while most of dolomite 
is from the replacement origin. In the formation of dolomite there are two distinct factor which are the source of $\mathrm{Mg}+$ (Magnesium) what's more, the procedure whereby the dolomitizing liquid is propelled over the carbonate sediments. ${ }^{1}$ To study the ancient dolomite five wideranging classes of dolomitization models are presently existing which are given below:

$$
\begin{aligned}
\text { i. } & \text { Evaporative Dolomitization } \\
\text { ii. } & \text { Seepage-reflux Dolomitization } \\
\text { iii. } & \text { Mixing-Zone Dolomitization } \\
\text { iv. } & \text { Burial Dolomitization } \\
\text { v. } & \text { Seawater Dolomitization }
\end{aligned}
$$

Every type comprising a unique form of dolomitizing fluid, way of flow and physical settings

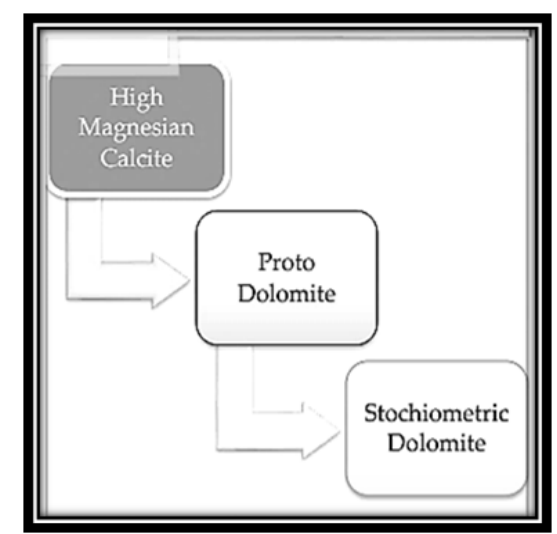

Figure I Showing the stages of dolomite formation.

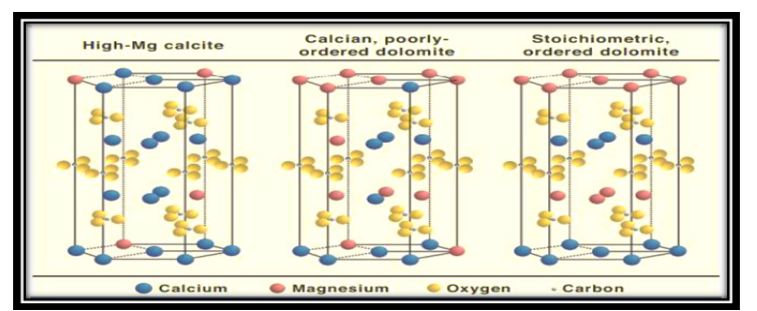

Figure $\mathbf{2}$ Showing the formation of high ordered dolomite from high-mg calcite.

\section{Evaporation dolomite}

Dolomite is in fact formed in high intertidal supratidal and sabkhas environment. Dolomitic that formed in the supratidal environment are precipitated from evaporated sea water. Early formation of gypsum and aragonite resulting to a sophisticated $\mathrm{Mg} / \mathrm{Ca}$ proportion of pore water to enhance the formation of dolomite.

\section{Seepage-reflux dolomitization}

This process comprises the formation of dolomitizing solutions over vaporization of lagoon water or tidal flat pore water besides then the succession of these solutions into nearby carbonate rocks (Figure 3).

\section{Mixing zone dolomitization}

This type of dolomite formed by the mixing of seawater with the fresh water. The source of water may be rainwater (Figure 4).

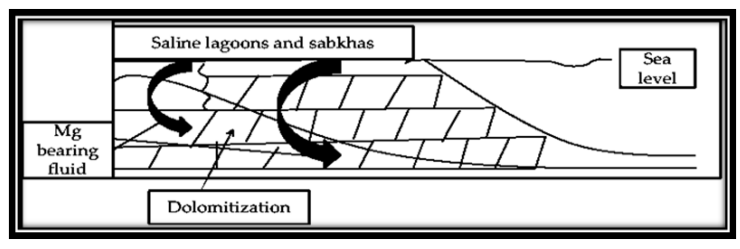

Figure 3 Figure showing dolomitizing fluid forming through evaporation.

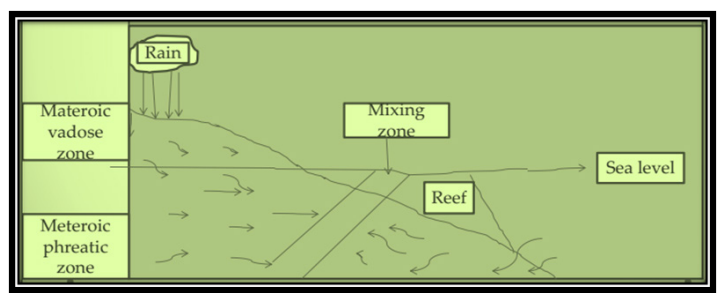

Figure 4 Figure showing water mixing zone.

\section{Burial dolomitization}

Burial dolomitization involves prime mechanism which is the dewatering of basinal mud rocks due to compaction and removal of Mg-rich fluids into neighboring shelf edge. Expulsion of water and changes of clay minerals with enlarged burial and increasing temperature suggest that it would liberate $\mathrm{Mg}$ ions along with $\mathrm{Fe}$ ion. The diagenesis of basinal shales are generally organic-rich and the diagenesis would contribute to $\mathrm{CO}_{3}$ ions. ${ }^{1}$

\section{Seawater dolomitization}

Seawater itself can also be a source of dolomite because it contains the sufficient amount of $\mathrm{Mg}$ ions with little modification if a good pumping process exists.

\section{Identification of dolomite}

In the lab, it is best to identify by staining it with the Alizarin Red Sulphate Solution.

Result. - The color of calcite will turn into red-brown, whereas dolomite will not be affected. In the field, it gives effervescence with $10 \% \mathrm{HCl}$ in the powdered form.

\section{Dedolimitization}

Dedolimitization refers to the partial to the whole transformation of former dolomite rocks to a calcian rich rock. The dolomitization can be considered as a kind of process in which $\mathrm{Mg}$ is gradually released. The dedolomitization process can be divided into two steps,

$$
\begin{aligned}
& \text { i. Dissolution of Dolomite } \\
& \text { ii. The precipitation of Calcite. }
\end{aligned}
$$

Dolomitization is a geological process by which the carbonate mineral dolomite is formed when magnesium ions replace calcium ions in another carbonate mineral, calcite. It is common for this mineral alteration into dolomite to take place due to evaporation of water in the sabkhas area. Dolomitization involves a substantial amount of recrystallization. This process is described by the stoichiometric equation. ${ }^{7}$

$$
2 \mathrm{CaCO}_{3 \text { (calcite) }}+\mathrm{Mg}^{2+} \leftrightarrow \mathrm{CaMg}\left(\mathrm{CO}_{3}\right)_{2 \text { (dolomite })}+\mathrm{Ca}^{2+}
$$

The conditions of dolomite formation are difficult to govern in 
the laboratory as up to yet no-one has been capable to form it at low temperatures from usual $\mathrm{H} 2 \mathrm{O}$. For undeviating result of dolomite formation the equation is:

$$
\mathrm{Ca}^{2+}+\mathrm{Mg}^{2+}+2\left(\mathrm{COl}^{-}\right) ;:=\mathrm{CaMg}\left(\mathrm{CO}_{3}\right)
$$

For complete dolomitization of a limestone sequence a large quantity of $\mathrm{Mg}^{2+}$ must be propelled over the formation. Beside existence of a favorable environment for chemical reaction, $\mathrm{a} \mathrm{Mg}^{2+}$ source and effectual transportation structure are required.

\section{Source of magnesium ion}

Prospective fluid sources are seawater and underground water of oceanic and/or meteoric source: while addition of magnesium can be added from high magnesium calcite and clays. Sea water is thought to be the prime source of magnesium ion for early diagenetic surface and near-surface dolomitization. It consists 1290 part per million magnesium (0.052 moles I-I) and 411 ppm Ca (0.01 moles I-I), i.e. an $\mathrm{Mg} / \mathrm{Ca}$ weight ratio of. 3.14 or molar proportion of 5.2. Beside meteoric water generally inconstant possess low values of both; for example, normal river water has $15 \mathrm{ppm} \mathrm{Ca}$ and $4 \mathrm{ppm} \mathrm{Mg}$ depicting a molar $\mathrm{Mg} / \mathrm{Ca}$ ratio of 0.44 . Therefore ocean water is usually thought to be the origin of the $\mathrm{Mg}^{2+}$ ions for maximum primary dolomitization but this water is generally altered in numerous dolomite forming models in trend. ${ }^{8}$

\section{Dolomitization model}

Dolomite is one of the complex mineral and its artificial occurrence is difficult to study in lab experimentations. Though it is a very wellordered mineral and demanding phase to precipitate, yet still dolomite synthesis at sedimentary tempratures using natural waters has not shown. Controlling chemical factors on dolomite formation from water is problematic to clarify and largely have been concluded from high-temperature experimentations ${ }^{9}$ (Figure 5). Figure 5 Essential elements of any dolomitization model, supply of $\mathrm{Mg}$ and the supply of carbonate must be sufficient to form the observed amount of dolomite there must be a delivery mechanism commonly in the form of fluid flow adequate to deliver these ions to the dolomitization site and lastly there must exist favorable condition for chemical reaction. For elucidation of primeval dolomite five extensive divisions of dolomitization model presently exists,
i. Evaporative
ii. Seepage-reflux
iii. Mixing-zone
iv. Burial
v. Seawater models (Figure 6), (Figure 7).

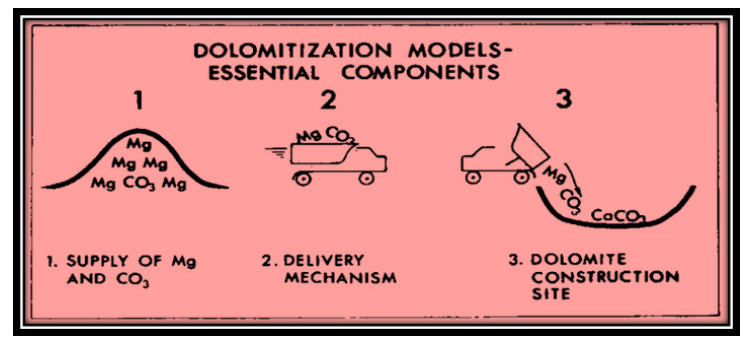

Figure 5 Essential elements of any dolomitization model.

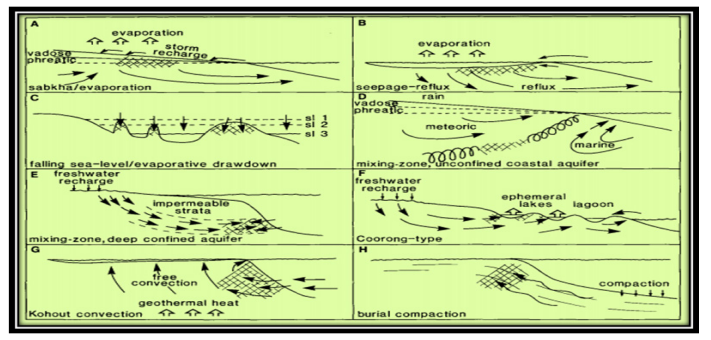

Figure 6 Models of dolomitization, illustrating the variety of mechanisms for moving dolomitizing fluids through the sediments. I

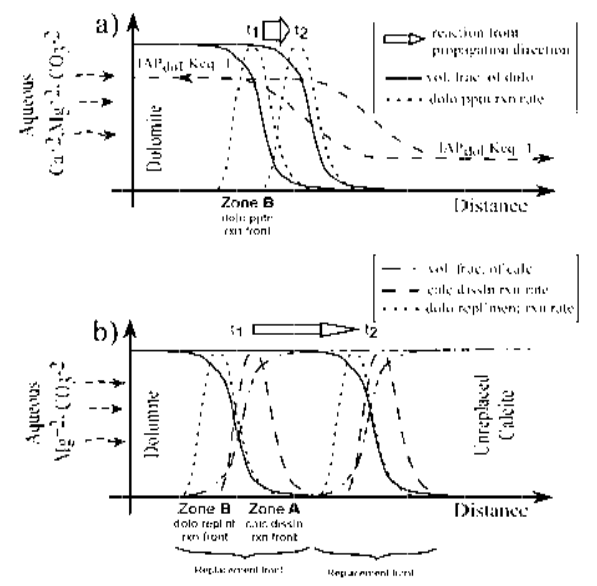

Figure 7 Conceptual models for (a) dolomite precipitation and (b) dolomite replacement scenarios.

Figure 7 Conceptual models for (a) dolomite precipitation and (b) dolomite replacement scenarios. (a) The thick black lines are the volume fraction of dolomite that is precipitation from the invading solution from the left. The dashed lines represent the dolomite precipitation rates $\mathrm{t}_{1}$ and $\mathrm{t}_{2}$ represent two different time slices. Dolomite precipitation front is moving towards the right as indicated by the open arrow. (b) The replacement front consists of two reaction zones namely zone A and zone B. In Zone A calcite chemically dissolves first releasing $\mathrm{Ca}^{+2}$ in the aqueous solution and producing secondary porosity. The $\mathrm{Ca}^{+2}$ thus released will eventually supersaturate the aqueous solution and precipitate dolomite that will pressure dissolve an equal amount of calcite in zone B. Again $t_{1}$ and $t_{2}$ represents two different time slices. Dolomite precipitation front is moving towards the right as indicated by the open arrow. ${ }^{10}$

\section{Replacement dolomite}

Formation of dolomite by replacement of $\mathrm{CaCo}_{3}$ ranges from fabric damaging to retaining and from fabric selective to persistent. The important aspects now are grain mineralogy and crystal extent, the timing of dolomitization and natural surroundings of dolomitizing liquids. Forms of dolomite crystals in replacement assortments differs from anhedral to euhedral shape, with the terminologies xenotopic and idiotopic denoting to the mosaics. Sibley ${ }^{11}$ put stress on the origin of crystal boundary shapes, identifying non-planar, euhedral and subhedral categories (Figure 8) (Figure 9). 


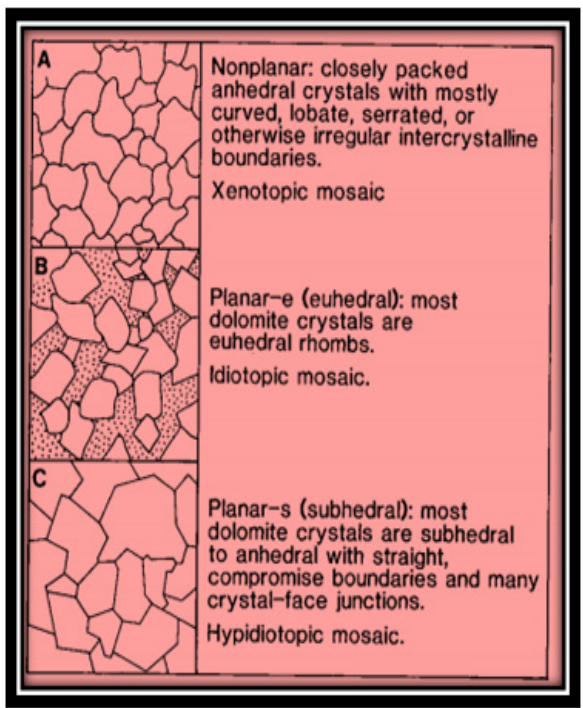

Figure 8 Three common dolomite textures; (A) Non-planar crystals in a xenotopic mosaic; (B) Planar-e crystals (e for euhedral) in an idiotopic mosaic; (C) Planar-s crystals (s for subhedral) in a hypidiotopic mosaic Sibley et al."

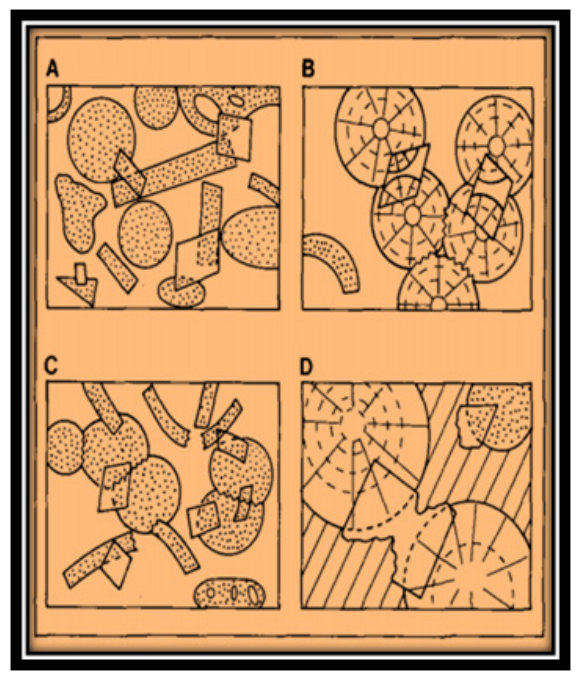

Figure 9 Common dolomite rhomb relationships in limestones; (A) Precompaction rhombs, grains in point contact. (B) Compaction after rhomb precipitation so that ghost textures in rhombs are displaced relative to grains; (C)Post-compaction rhombs including fractured grains and stylolites; (D) Pre-sparite rhombs etched and replaced.'

\section{Dolomite cement}

Though dolomite is mainly a replacement, cement of this mineral are common. In Plio-Pleistocene dolomites of the Caribbean-Bahamas, dolomite cement generally formed amongst dolomitized grains and in the spaces. The dolomite can also be found as clear spur, straight analogous to calcite spar, although usually cement is just a single layer of large rhombs in between the spaces of grains. Crystals are too clear and thus they are known as limpid for their white look. Stress has been put on these, proposing they are a distinctive creation of mixing-zone dolomitization. In few cases, dolomite cement comprises regions of syntaxial calcite depicting fluctuation in pore water chemistry (Figure $10) .^{12}$

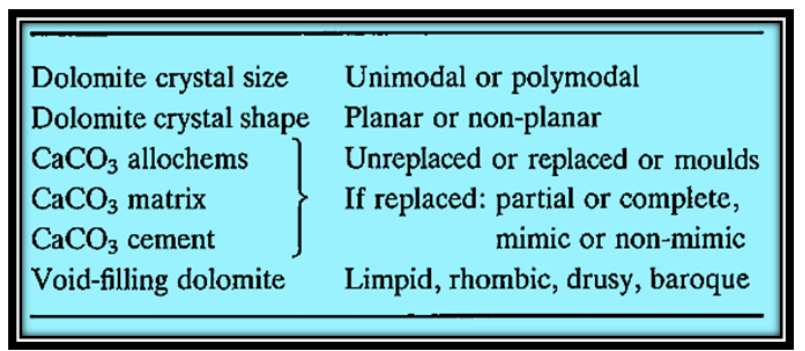

Figure 10 Terms for describing dolomite textures after Sibley et al. ${ }^{\text {I }}$

\section{Baroque dolomite}

This specific dolomite is also known as saddle or white sparry dolomite. Baroque dolomite is known to be forming as a result of replacement. In the minerals collecting community, it is known as pearl spar distinguished by a distorted crystal lattice it has bowed crystal looks, curved cleavage planes, having undulose extinction. Crystal of this dolomite which is larger than a millimeter is generally a compound of sub-crystals, resulting in stepped surface of the crystal. If the dolomite is of replacement origin fluid inclusions, and calcite relics will be present which provides the crystals a gloomy look in thin section and displays shining lustre in hand specimens. Baroque dolomite is calcium rich and usually having Fe content (up to 15 mole $\% \mathrm{FeCO}_{3}$. Dissimilarities in configuration of separate crystals are normally distinct, happening amongst dissimilar growing sheets giving a different zonation and inside the regions themselves. This dolomite takes place as together an opening fill and a replacement. In its cavity-fill approach, it typically consumes a xenotropic texture of asymmetrical crystal borders inside the assortment but bowed, scimitar-like ends into the void. ${ }^{13}$

\section{Conclusion}

The objective of this article has been twofold, first to outline and clearly explain the dolomite its types and formation and then to outline clearly the models for dolomitization and to review the different factors associated with dolomite. Dolomite is by formation a very complex which not only forms in the ocean by the simple addition of $\mathrm{Mg}$ but also forms as result of Evaporization and burial of magnesium-containing water upon reaction with limestone. Different dolomite types have their own history embedded within it. Baroque a specific category of dolomite which may be cement or a replacement is, also called 'white sparry' dolomite and identified to mineral accumulators as pearl spar. The criteria for choosing between models are not definitive as could be desired and many of these criteria have been interpreted in more than one way. A considerable measure of work and research is anticipating to be completed identified with dolomite, its development and dolomitization process.

\section{Acknowledgements}

None.

\section{Conflict of interest}

The author declares there is no conflict of interest.

\section{References}

1. Tucker ME, Wright PV. Carbonate sedimentology. Oxford, United Kingdom: Blackwell. 1990;482.

2. Pichler T, Humphrey JD. The formation dolomite in island-arc 
sediments due to gas-seawater-sediment interaction. Jour Sediment Res. 2001;71(3):394-399.

3. Wells A. Recent Dolomite in the Persian Gulf. Nature. 1962;194:274-275.

4. Weyl PK. Pressure solution and the force of crystallization-A phenomenological theory. Jour Geophys Res. 1959;64:2001-2025.

5. Kaczmarek SE, Sibley DF. A comparison of nanometer-scale growth and dissolution features on natural and synthetic dolomite crystals: implications for the origin of dolomite. Jour Sediment Res. 2007;77(5):424-432.

6. Merino E, Canals A. Self-accelerating dolomite for calcite replacement: self organized dynamics of burial dolomitization and associated mineralization. Amer Jour Sci. 2011;311(7):573-607.

7. Sibley DF. The origin of common dolomite fabrics. J sedim Petrol. 1982;52:1987-1100.
8. Patterson RI, Kinsman DJJ. Formation of diagenetic dolomite in coastal sabkhas along the Arabian (Persian) Gulf. Bull Am Ass petrol Geol. 1982;66:28-43.

9. Zenger DH. Dolomitization and unifonnitarianism. J geol Educ. 1972;20(3):107-124.

10. Banerjee A. Estimation of dolomite formation: Dolomite precipitation and dolomitization. Journal of the Geological Society of India. 2016;87(5):561-572.

11. Sibley DF, Gregg JM. Classification of dolomite rock texture. J sedim Petrol. 1987;57:967-975.

12. Folk RL, Land $\mathrm{LS}$. $\mathrm{Mg} / \mathrm{Ca}$ ratio and salinity, two controls over crystallization of dolomite. Bull Am. 1975;59(1):60-68.

13. Radke BH, Mathis RL. On the formation and occurrence of saddle dolomite. I sedim Petrol. 1980;50:1149-1168. 